\title{
The toxic effect of zinc oxide nanoparticles on the terrestrial slug Lehmannia nyctelia (Gastropoda-Limacidae)
}

\author{
Wafaa A. Mohammad ${ }^{1}$ Safaa M. Ali $^{2^{*}} \mathbb{D}$, Nasser Farhan ${ }^{3}$ and Shimaa Mohamed Said ${ }^{2}$
}

\begin{abstract}
Background: Chemicals have deleterious effect on the environment. The wide use of nanomaterials as products for plant protection, fertilizers, and also in water purification leads to the release of these materials to the environment. Terrestrial gastropods including snails and slugs have the ability to accumulate heavy metals in their bodies. The present study evaluates the toxic effect of zinc oxide nanoparticles on the terrestrial slug Lehmannia nyctelia. Zinc oxide nanoparticles (ZnO NPs) were prepared by thermal decomposition method. ZnO NPs are characterized by Xray diffraction (XRD), Fourier transform infrared spectroscopy (FTIR), scanning electron microscopy (SEM), and ultraviolet-visible spectroscopy (UV). Slugs were treated with three different concentrations of ZnO NPs.
\end{abstract}

Results: A total of three animals died by the end of the experiment. Many histological alterations were detected after exposure to different concentration of ZnO NPs.

Conclusions: The obtained histological alterations prove the toxic effect of ZnO NPs on the animal under study.

\section{Background}

Molluscs are considered as one of the important animals in the food chain and noticed as agricultural pests. Toxic chemicals produce harmful effect on terrestrial gastropods at the cellular level (Boer et al., 1995; Hernadi et al., 1992). At the same time, they possess special mechanisms to get rid of several harmful chemicals which accumulated in their tissues (Ferner, 2001).

Slugs are considered as a great threat to many of the temperate horticultural crops. Seedlings are very sensitive to slug as if they cause a little amounts of damage to the growing tips of seedlings, this will lead to plant death (Moens \& Glen, 2002; Nash et al., 2007).

Slug Lehmannia valentiana is a pest which result in many troubles to greenhouse. The common method to control this slug is the chemical molluscicides. The chemical molluscicides may cause undesirable side

\footnotetext{
* Correspondence: safaa.mohamed1@science.aun.edu.eg

${ }^{2}$ Zoology Department, Faculty of Science, Assiut University, Assiut, Egypt

Full list of author information is available at the end of the article
}

effects such as toxicity of non-target organisms, contamination of food and environment (Jeong et al., 2012).

Terrestrial gastropods are one of the most efficient accumulators of metals and they are considered as bioindicators to environmental pollution (Pihan \& de Vaufleury, 2000; Snyman et al., 2005; Viard et al., 2004). Terrestrial snails and slugs have a great capacity of the accumulation and magnification of heavy metals and are considered important species to monitor the bioavailability of metallic components in the soil if they compared to other invertebrates (Coeurdassier et al., 2000; Lanno \& Mc Carty, 1997; Wensen et al., 1994).

Recently, the industrial development in agricultural field increased rapidly and leads to inorganic and organic contamination from harmful heavy metals and chemicals to the terrestrial and aquatic ecosystems. These chemicals show deleterious effect on aquatic and terrestrial environment (Davidson et al., 2011; Pack et al., 2014; Sanchez, 2008).

Nanomaterials were widely used in agriculture during the last 10 years (Buzea \& Pacheco, 2017; Gogos et al.,
Springer Open
(C) The Author(s). 2021 Open Access This article is licensed under a Creative Commons Attribution 4.0 International License, which permits use, sharing, adaptation, distribution and reproduction in any medium or format, as long as you give appropriate credit to the original author(s) and the source, provide a link to the Creative Commons licence, and indicate if changes were made. The images or other third party material in this article are included in the article's Creative Commons licence, unless indicated otherwise in a credit line to the material. If material is not included in the article's Creative Commons licence and your intended use is not permitted by statutory regulation or exceeds the permitted use, you will need to obtain permission directly from the copyright holder. To view a copy of this licence, visit http://creativecommons.org/licenses/by/4.0/. 
2012). They were using as plant protection products, fertilizers, water purification, for soil improvement, and pollutant remediation (Parisi et al., 2015). In many cases, nanoparticles (NPs) are applied to the soil directly as a fertilizer or in the form of an aerosol (Sturikova et al., 2018) while seeds are mostly soaked in aqueous NP suspension (Lin \& Xing, 2007; Segatto et al., 2018). In the future, technological application of NPs may be undesired as they are released to the environment and diffused in the soil due to their small size (Kaegi et al., 2008).

Zinc oxide nanoparticles ( $\mathrm{ZnO}$ nanoparticles) are interesting materials due to their unique electrical and optical properties, their wide-band semiconductor, and they are suitable for many applications (Mishra et al., 2011). ZnO NPs are useful in environmental remediation due to their high capabilities for degradation and elimination of pollutants in air or water due to their strong physical adsorption and their chemical catalytic properties (Jing et al., 2001). Zn ONPs are used as antimicrobial agent, and also used in cosmetics, sunscreens, and coatings (Ali et al., 2012). Due to the increasing use in consumer products, $\mathrm{ZnO}$ NPs will be found in the atmospheric, terrestrial, and aquatic environments (Ali et al., 2012; Sales, 2013; Service, R.F., 2008).

The present study aimed to evaluate the toxic effect of ZnO NPs on theterrestrial slug Lehmannia nyctelia.

\section{Methods}

\section{Chemicals and reagents}

All chemical and reagents purchased were analytical grade. Zinc nitrate hydrate was purchased from Alfa Aesar (Ward Hill, MA), Ethanol, abs. 100\% a.r. was procured from Chem-Lab., Belgium.

\section{Preparation of $\mathrm{ZnO}$ nanoparticles}

The zinc oxide nanoparticles ( $\mathrm{ZnO} \mathrm{NPs}$ ) were prepared by thermal decomposition method as described by Shankar et al. (2013). Three grams of zinc nitrate were taken and fired in a furnace (air atmosphere) for $3 \mathrm{~h}$ at $500{ }^{\circ} \mathrm{C}$. It was further grinded in a mortar to make a fine powder of $\mathrm{ZnO}$ NPs.

\section{Characterization of ZnO NPs}

$\mathrm{ZnO}$ NPs were characterized by X-ray diffraction (XRD), Fourier transform infrared spectroscopy (FTIR), scanning electron microscopy (SEM), and ultraviolet-visible spectroscopy (UV).

\section{X-ray diffraction (XRD)}

The structure of the nanoparticles was investigated by a Philips X-ray diffractometer (model PW 1720) at room temperature, with a step of $0.06^{\circ}$, in the range of $4^{\circ} \leq 2 \theta$ $\leq 89.89^{\circ}$. The average crystallite sizes were calculated by applying Scherrer's equation: $D=\mathrm{K} \lambda / \beta \cos \theta$, where $K$ is the shape factor whose value is taken as $0.89, \lambda$ is the wavelength of $\mathrm{Cu} K \alpha$ radiation $(\lambda=1.54178)$, and $\beta$ is the corrected full width at half maximum (FWHM) of the diffraction peak and $\theta$ is the diffracting angle.

\section{Fourier transform infrared spectroscopy (FTIR):}

Infrared spectra were recorded on a Thermo Fishermodel: Nicolet iS10 FTIR spectrometer in a wave number range $4000-500 \mathrm{~cm}^{-1}$.

\section{SEM and TEM}

The morphology of the ZnO NPs powder sample was investigated by scanning electron microscopy (SEM; JEOL [model: JSM 5400LV]) and transmission electron microscopy (TEM; JEOL [model: JEM-100 CXII]).

\section{UV-visible spectroscopy}

The UV-vis absorption measurements of $\mathrm{ZnO}$ NPs were recorded in the range $200-800 \mathrm{~nm}$ by PerkinElmer; model: LAMBDA $750 \mathrm{UV} / \mathrm{Vis} / \mathrm{NIR}$ Spectrophotometer. The synthesized $\mathrm{ZnO}$ NPs powder sample was dispersed in ethanol and optical characterizations were executed.

\section{Collection of specimens}

The experimental work was carried out using specimens of Lehmannia nyctelia, collected during autumn from Assiut University farm, Assiut Governorate, Egypt. Slugs were kept in normal laboratory conditions, maintained in plastic containers containing soil obtained from their natural habitat and fed with fresh lettuce daily.

\section{Experimental design and $\mathrm{ZnO}$ NPs exposure}

For the experiment, the acclimatized healthy slugs with an equal body weight $(0.6 \mathrm{gm})$ were randomly distributed into four groups (control and three treated groups). Each group consists of 10 individuals and was kept in plastic containers containing the same weight of soil and each container covered with perforated cloth for ventilation. The control slug's group fed on fresh lettuce impressed in $10 \mathrm{ml}$ distilled water.

However, the treated groups were fed on fresh lettuce impressed in different concentrations of $\mathrm{ZnO}$ NPs $(0.01$ $\mathrm{g} / 10 \mathrm{ml} \mathrm{dw}, 0.02 / 10 \mathrm{ml} \mathrm{dw}, 0.05 / 10 \mathrm{ml} \mathrm{dw}$, modified from Fahmy and Abdel-Ghaffar (2014). Exposure period was 10 days, during which the slugs were subjected twice to the contaminated food with the previously mentioned concentrations of $\mathrm{ZnO}$ NPs. At the end of the experimental period, surviving slugs were used for histological studies. Died animals were counted and removed.

Slugs were fixed in neutral formalin and prepared for histological study. Seven micrometers transverse sections were prepared and stained with hematoxilin and eosin (HE). Sections were examined by light microscope. The 
organs under study are the digestive gland, salivary glands, and hermaphroditic glands.

\section{Results}

Characterization of $\mathrm{ZnO}$ nanoparticle $X$-ray diffraction $(X R D)$

The ZnO NPs were characterized by X-ray diffraction (XRD). A definite line broadening of the XRD peaks indicates that the prepared material consists of particles in the nanoscale range (Fig. 1a). All the diffraction peaks can be indexed to the $\mathrm{ZnO}$ hexagonal wurzite structure (JPCDS card number: 04-008-8196). The average particle size of the sample was found to be $21 \mathrm{~nm}$ which is derived from the full width at half-maximum (FWHM) of more intense peak corresponding to (Shankar et al., 2013) plane located at $36.34^{\circ}$ using Scherrer's formula.

\section{FTIR analysis}

Figure $1 \mathrm{~b}$ shows the FTIR spectrum of the zinc oxide nanoparticles. The special peak at $500 \mathrm{~cm}^{-1}$ owing to $\mathrm{Zn}-\mathrm{O}$ vibrational mode (18-19); another strong band at $1013 \mathrm{~cm}^{-1}$ may be assigned to the stretching and bending vibrational modes of the $\mathrm{Zn}-\mathrm{O}$ bonds, respectively.

\section{Electron microscopic investigation of ZnO NPs}

The morphology of ZnO NPs was characterized by SEM and TEM techniques. Figure 2a shows the SEM image;

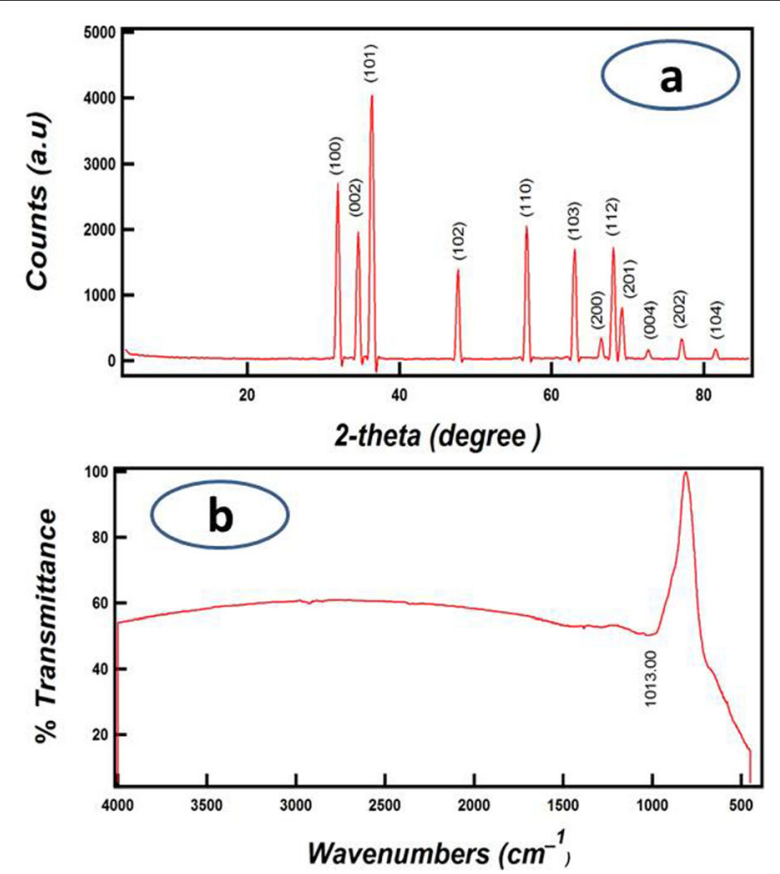

Fig. 1 a X-ray diffraction patterns of ZnO NPs. The peaks refer to the Wurtzite hexagonal structure in the reference data (JCPDS No. 04008-8196). b FTIR Spectra of ZnO NPs while Figure $2 \mathrm{~b}$ presents a typical TEM image of $\mathrm{ZnO}$ NPs. It is clear that in this case a ZnO NPs was successfully prepared.

\section{The UV-Vis spectrum}

The UV-Vis spectrum of ZnO NPs is shown in Fig. 2c. Confirmation of the synthesized $\mathrm{ZnO}$ product in nanoscale was exhibited by the highly red shifted absorption maximum occurring around $400 \mathrm{~nm}$ (Datta et al., 2017). No other peaks were observed in the spectrum, confirming that the synthesized product was $\mathrm{ZnO}$ only.

\section{Results of histology}

At the end of the experiments, three animals died; one after exposure to concentration $0.02 \mathrm{~g} / 10 \mathrm{ml} \mathrm{dw} \mathrm{ZnO}$ NPs and two died after exposure to $0.05 \mathrm{~g} / 10 \mathrm{ml} \mathrm{dw}$ ZnO NPs.

\section{Histological observation of the digestive gland (Fig. 3a-d)}

Untreated slugs The digestive gland of the slug composes of lobes. Each lobe composes of large number of digestive tubules separated with loose connective tissue. Each tubule is surrounded externally with circular muscle layer. The digestive acini are lined with simple epithelial cells which arranged around narrow irregular lumen (Fig. 3a).

There are four different cell types were observed lining the digestive gland tubules. The two main cell types are digestive and calcium cells. The third type of cells is excretory cells, while the fourth type comprises thin cells which distribute randomly between the different cells. These cells have the following characteristic features:

Digestive cells

They are the most abundant cell type in the digestive gland tubule epithelium. These cells are observed as a simple columnar epithelium with flattened or slightly broad apical surfaces and narrow base. They appear under the light microscope with highly vacuolated cytoplasm.

Calcium cells

These cells are fewer than digestive cells. They are pyramidal in shape with narrow distal end and broad base. Calcium cells are basophilic cells, mostly have large rounded nuclei.

Excretory cells

They are basophilic cells and globular in shape.

Thin cells

These cells are narrow extending to the full height of the epithelium.

Slugs exposed to $0.01 \mathrm{~g} / 10 \mathrm{ml} \mathrm{dw} \mathrm{ZnO}$ NPs The epithelial cells became shorter. Some of them are ruptured and lost their content. The lumen in some acini of 

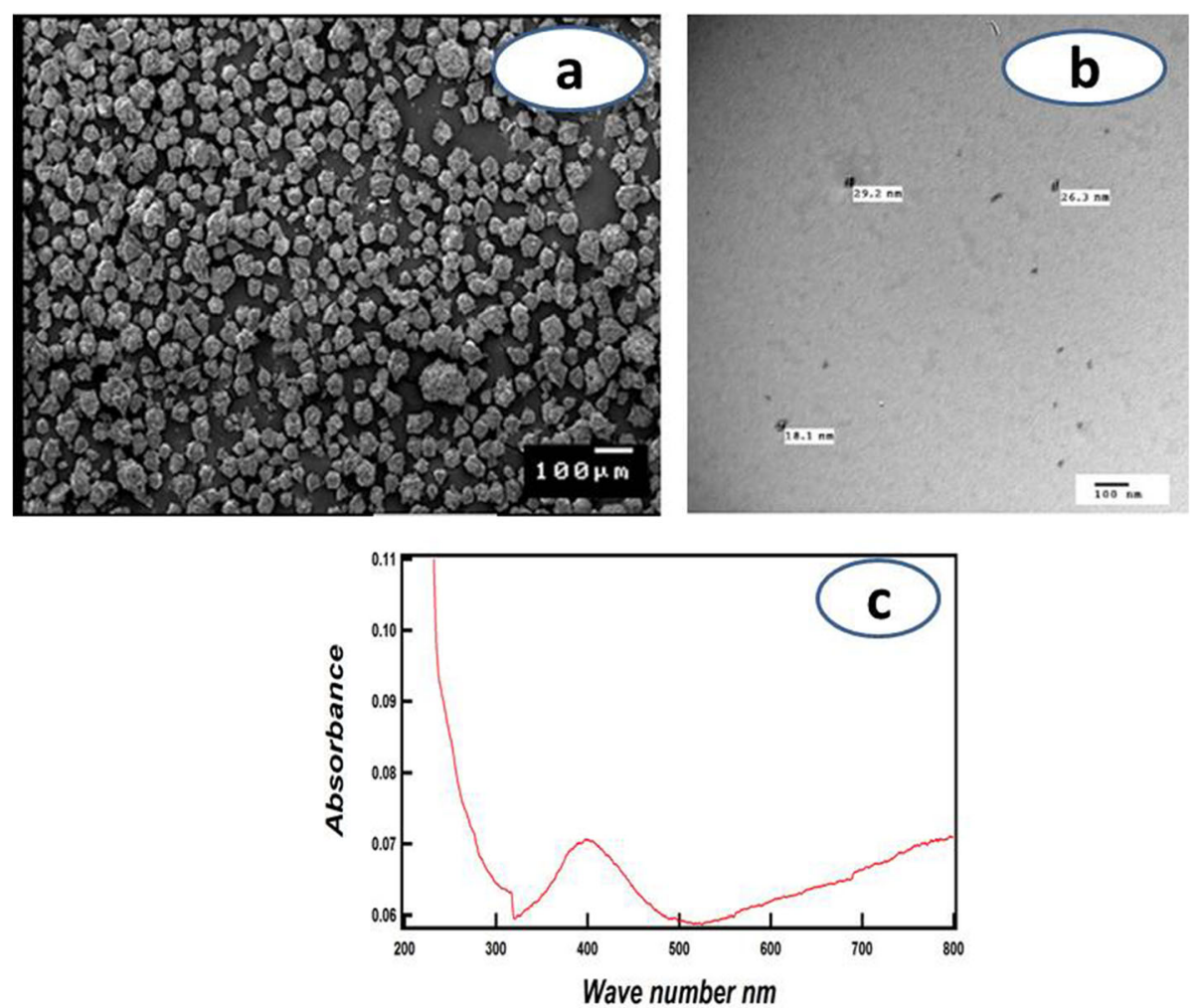

Fig. 2 a SEM image of ZnO NPs. b TEM image of ZnO NPs. c UV-Vis analysis of ZnO NPs

digestive gland increased in size and filled with the cells remains (Fig. 3b).

Slugs exposed to $0.02 \mathrm{~g} / 10 \mathrm{ml} \mathrm{dw} \mathrm{ZnO}$ NPs Some digestive tubules were separated from the surrounding muscle layer. Many cells are ruptured and lost their contents. Large vacuoles are detected in many cells. The lumen of the acini became narrow (Fig. 3c).

Slugs exposed to $0.05 \mathrm{~g} / 10 \mathrm{ml} \mathbf{d w} \mathrm{ZnO}$ NPs: The connective tissue among acini is destroyed leaving large empty spaces. Most of the epithelial cells were ruptured. The acini became narrow and contain cells remains (Fig. 3d).

\section{Histological observations on the salivary gland:}

Untreated slugs (Fig. 4a) The examination of the untreated slug's salivary gland showed that it consists of three types of glandular cells. These types showed great variation in their contents and staining properties; type (I) has purple color, type (II) has a blue color and type (III) is a vacuolated cell.

Slugs exposed to $0.01 \mathrm{~g} / 10 \mathrm{ml} \mathrm{dw} \mathrm{ZnO}$ NPs The salivary gland showed many histological changes (Fig. $4 \mathrm{~b}$ ).
Many cells lost their contents and the vacuolated cells increased in number.

Slug exposed to $0.02 \mathrm{~g} / 10 \mathrm{ml} \mathrm{dw} \mathrm{ZnO}$ NPs Many histological changes were observed (Fig. 4c). Most of the acidophilic and vacuolated cells lost their shapes and their nuclei became smaller in size, flattened, and marginal in position. Large spaces were appeared among different cell types.

Slug exposed to $0.05 \mathrm{~g} / 10 \mathrm{ml} \mathrm{dw} \mathrm{ZnO}$ NPs Acidophilic cells increased in number and most of them became smaller in size, with flattened and marginal nuclei (Fig. 4d). Many vacuolated cells lost their content and became empty cells.

\section{Histological observation of gonads: (Fig. 5a-d)}

Untreated slugs The hermaphroditic gland of the slug is composed of a small number of lobes; each lobe consists of various acini separated by thin interstitial connective tissue and enveloped by squamous epithelial cells (Fig. 5a). Walls of the acini are lined with clusters of germinal epithelial cells and all acini contain different stages of developed cell as a result of both oogenesis and spermatogenesis. 

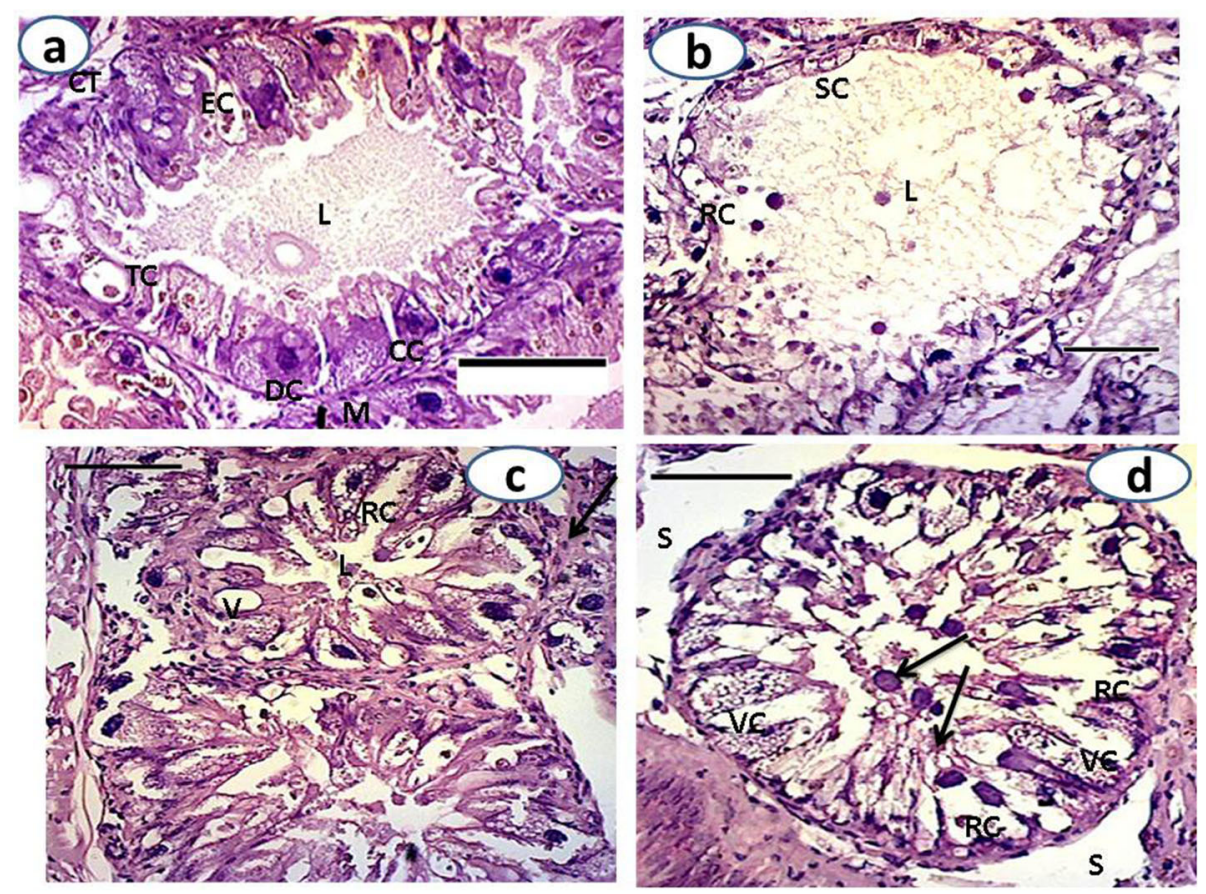

Fig. 3 Photomicrograph of sections through the digestive gland of a untreated slugs showing: connective tissue (CT), digestive cells (DC), thin cells (TC), calcium cells (CC), and lumen (L). b Slugs treated with $0.01 \mathrm{ZnO} N P s$ showing: large lumen (L), shorter cells (SC), and ruptured cells (RC). c Slugs treated with $0.02 \mathrm{ZnO}$ NPs showing: vacuoles(V), ruptured cells (RC), and separated muscle (arrows). d Slugs treated with $0.05 \mathrm{ZnO}$ NPs showing: remains cells (arrows), vacuolated cells (VC), ruptured cells (RC), and space (S)

Slug exposed to $0.01 \mathrm{~g} / 10 \mathrm{ml} \mathrm{dw} \mathrm{ZnO}$ NPs Degenerative changes were observed in most of different stages of gametogenesis (Fig. 5b). The squamous epithelial layer that surrounded the acini is ruptured in some places. Large empty spaces appeared among the acini. Blood cells infiltration is detected. Some sperms are degenerated.

Slug exposed to $0.02 \mathrm{~g} / 10 \mathrm{ml} \mathrm{dw} \mathrm{ZnO}$ NPs Signs of degeneration in different gametogenesis stages were detected. They were represented by fibrosis and appearance of many spaces in the acini lumen, in addition to appearing large spaces among acini (Fig. 5c).

Slug exposed to $0.05 \mathrm{~g} / 10 \mathrm{ml} \mathrm{dw} \mathrm{ZnO}$ NPs The early gametogenesis stages increased in number and aggregated in clusters (Fig. 5d). Many of the gamete's stages lost their shapes and degenerated. Fibrosis in the lumen of acini was increased.

\section{Discussion}

Land snails are considered as serious pests in filed crops in many parts of the world. They result in damage and great losses in various vegetation fields (El-Okda, 1981; Gabr et al., 2007; Ramzy, 2009). Zinc oxide (ZnO) considers one of the most used types of metal-based NPs, with the third largest annual production in volume
(Merdzan et al., 2014; Romero-Freire et al., 2017). It also uses as antibacterial agent and fertilizer (Ma et al., 2013; Parisi et al., 2015; Segatto et al., 2018).

Results obtained from infrared spectra that recorded in the present study showed that the special peak at 500 $\mathrm{cm}^{-1}$ owing to $\mathrm{Zn}-\mathrm{O}$ vibrational mode(18-19); another strong band at $1013 \mathrm{~cm}^{-1}$ may be assigned to the stretching and bending vibrational modes of the $\mathrm{Zn}-\mathrm{O}$ bonds, respectively (Kumar et al., 2015; Punnoose et al., 2014). The FTIR spectra of ZnO NPs showed that the high purity of $\mathrm{ZnO}$ NPs was prepared by thermal decomposition method.

The present histological investigations of the digestive gland of land slug Lehmannia nyctelia confirm the existence of four cell types: digestive, calcium, excretory, and thin cells. This finding is agreed with results of Hamed et al., 2007; Abo Bakr (2011) and Yousef et al. (2011) in the land snail, Eobania Vermiculat. Sharaf et al. (2015) as well as Mustafa and Awad (2018) revealed that the digestive gland is consisted of three types of cells in the land snail Helicella vestalis and in the slug Lehmannia marginata, respectively. Moreover, the digestive gland was reported to be composed of two cell types only in both the land snail Eobania vermiculata ( Zaldibar et al., 2007) and the slug Limax maximus (Abdel-Haleem \& EI-Kassas, 2013). 


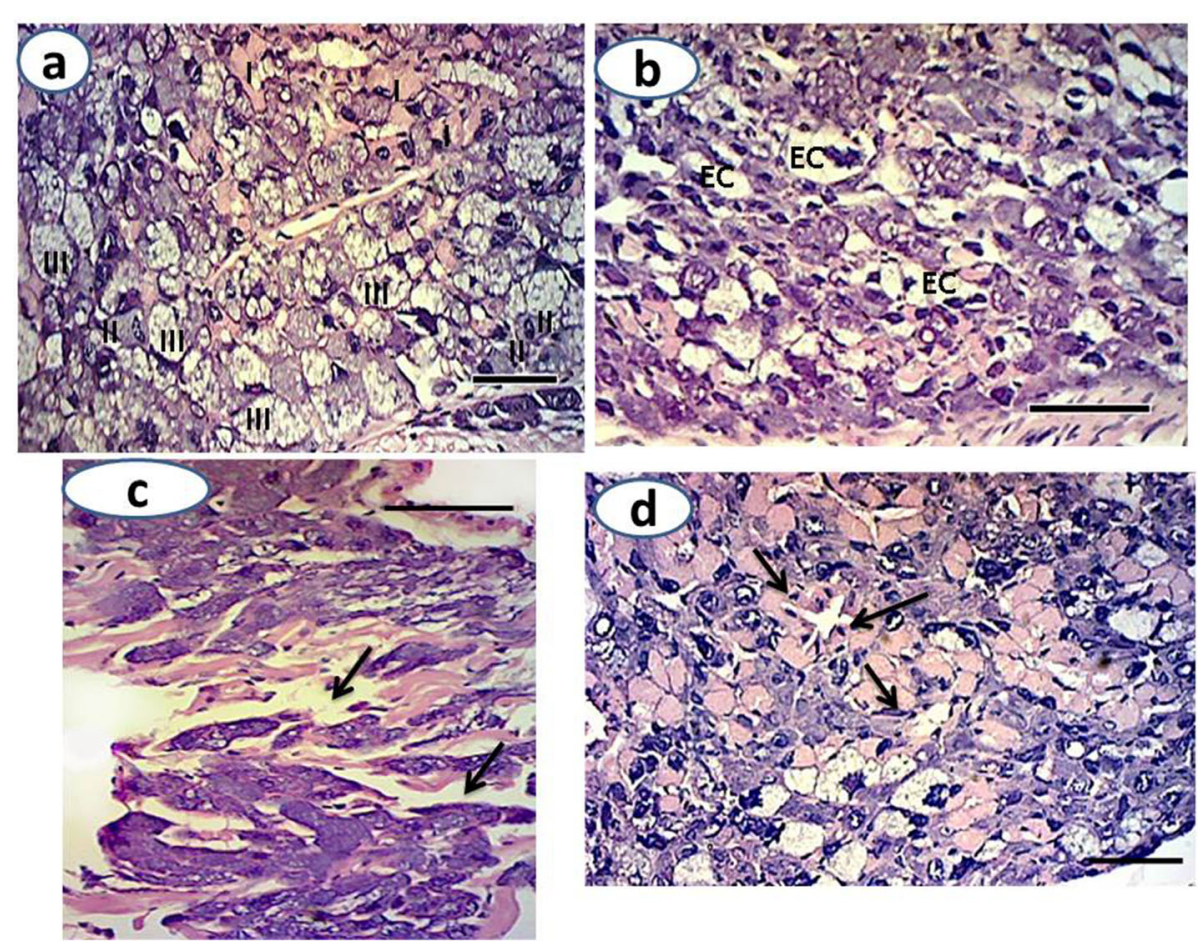

Fig. 4 Photomicrograph of sections through the salivary gland of a untreated slugs showing three types of cells: (I) purple colored cells, (II) blue colored cells, and (III) vacuolated cells. b Slugs treated with 0.01 ZnO NPs showing: empty cells(EC). c Slugs treated with 0.02 ZnO NPs showing acidophilic cells with flattened marginal nuclei (arrows). d Slugs treated with $0.05 \mathrm{ZnO}$ NPs showing spaces between cells (arrows)

In slugs and snails, the digestive gland is the major site for metal accumulation (Berger \& Dallinger, 1993; Marigo'mez et al., 2002), and plays a critical role in metal detoxification (Kammenga et al., 2000). In the present study cytoplasmic vacuolation and degeneration was noticed in the digestive acini of treated slug Lehmannia nyctelia. These results are in accordance with that obtained by Abdel-Haleem and EI-Kassas (2013) who studied the effect of three plant extracts on Limax maximus. Additional histological changes such as tubular disruption in the digestive tubules were observed. Sharaf et al. (2015) reported the same result in the digestive gland of land snail Helicell vestalis treated with some pesticides.

Bour et al. (2015) suggested that when NPs are ingested, they may get stuck in the digestive tract and not be absorbed but promote physiological changes that cause damage to the organism, such as a decrease in the absorption of nutrients. Hooper et al. (2011) raised the possibility that a fraction of $\mathrm{Zn}$ accumulated in Eisenia veneta organisms through NPs is present in the nanoform, remaining intact inside the cell but still affecting its metabolism.

In the present study, the salivary glands of Lehmannia nyctelia revealed that there are three different cell types: type (I) purple colored cells, type (II) blue colored cells, and type (III) vacuolated cells. These results are in accordance with Mustafa and Awad (2018) who revealed that the salivary glands of $L$. maximus possess three types of cells. In contrast, Abdel Gawad et al. (2018) reported four different cell types comprised mucocytes I, mucocyte II, vacuolated cells, and granular cells in salivary gland of Eobania vermiculata.

The present histological observations in the cells of the salivary gland of Lehmannia nyctelia treated with ZnO NPS revealed cytoplasmic vacuolation and disintegration of the digestive tubules epithelial cells. These findings are similar to the results reported by Mustafa and Awad (2018) who found vacuolated cytoplasm and degenerated nuclei in the cells of salivary gland of slug Limax maximus after treatment with thymol.

In the present work, the histological alterations when ovotestis of the Lehmannia nyctelia is exposed to $\mathrm{ZnO}$ NPs, the disruptions within acini and gametic cells were observed. Elsewhere, some alterations were observed such as, spermatocytic degeneration, disruptions of oocytes, and appearing fibrosis in the lumen of acini. Wangsomnuk et al. (1997) noticed the same results in Indoplanorbis exustus. Additionally, Zhou et al. (1993) noticed reduction in the number of spermatozoa and oocytes in Biomphalaria glabrata after the exposure to niclosamide.

Dimkpa et al. (2011) and Heggelund et al. (2014) decided that accumulation of NPs causes disorders in the cells which led to toxicity through the formation of 


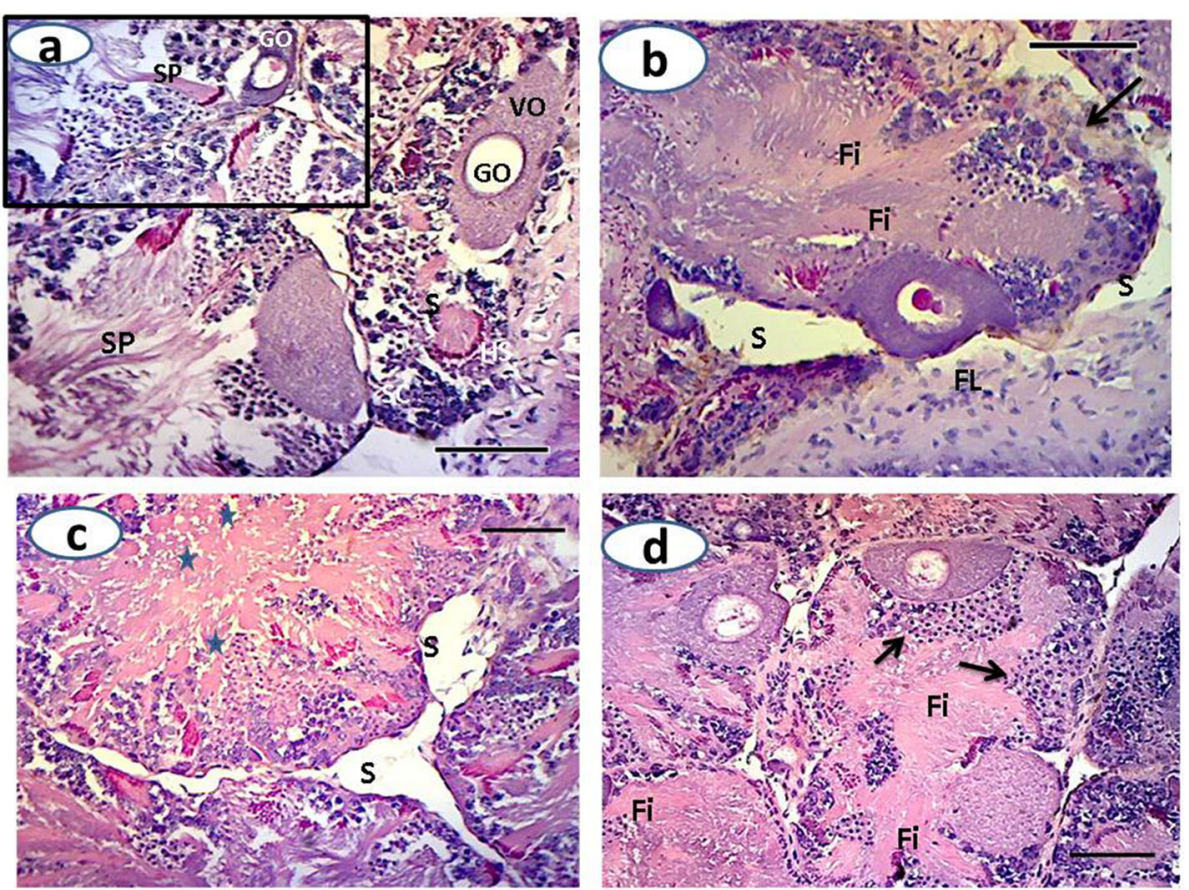

Fig. 5 a Photomicrograph of sections through the gonads shows: spermatocyte (SC), spermatids (S), numerous spermatozoa (SP), growing oocytes (GO), and vitellogenic oocytes (VO). b Slugs treated with 0.01 ZnO NPs showing fibrosis (Fi), blood cells infiltration (FL), space (S), and the simple squamous cells layer ruptured in some positions (arrows). c Slugs treated with $0.02 \mathrm{ZnO}$ NPs showing empty spaces (S) and fibrosis (stars) and $\mathbf{d}$ slugs treated with $0.05 \mathrm{ZnO}$ NPs showing fibrosis (Fi) and aggregation of early gametogenesis stages(arrows)

reactive oxygen species (ROS). Pinto et al. (2003) revealed that the reactive oxygen species (ROS) has toxic effect in the biological system, which disrupts normal cellular processes.

The present histopathological examinations indicated that, $\mathrm{ZnO}$ NPs induced toxicity in cells of digestive gland, salivary glands, and hermaphroditic gland in Lehmannia nyctelia.

\section{Conclusion}

In conclusion, $\mathrm{ZnO}$ NPs caused denaturation of the animal organs which lead to abnormal functions of these organs and finally affect its fitness. The extensive use of $\mathrm{ZnO}$ NPs will lead to destructive effects on animals and will pollute the environment. The present study indicated that Lehmannia nyctelia can be used as bioindicator to the pollution of the terrestrial environment.

\section{Abbreviations}

ZnO NPs: Zinc oxide nanoparticles; ROS: Reactive oxygen species; FTIR: Fourier transform infrared spectroscopy; FTIR: Fourier transform infrared spectroscopy; SEM: Scanning electron microscopy; TEM: Transmission electron microscopy; UV-visible spectroscopy: Ultraviolet-visible spectroscopy

\section{Acknowledgements}

The authors would like to express their thanks to Prof. Dr. Ahmed Hamed, Prof. Dr. Naser El Shimy, and Dr. Torkia Abul-Maged for their continuous help and advice.
Committee's reference number

Not available

\section{Authors' contributions}

WAM, SMA, SMS, and NMF designed the practical part of the work. NMF prepared, characterized ZnO NPs, and analyzed data obtained from nanoparticles characterization. WAM and SMS collected animals from the field and carried out the animal experiment. SMA carried out the data analysis, prepared figures, and wrote the manuscript. All authors read and approved the final manuscript.

\section{Funding}

Not applicable

\section{Availability of data and materials}

Data generated during this study are included in this published article. Please contact authors for data.

\section{Declarations}

Ethics approval and consent to participate

All procedures and experiments with animals in this study were approved by the Animal Care and Use Committee at the National Health Research Institute, Egypt.

Consent for publication

Not applicable

\section{Competing interests}

The authors declare that they have no competing interests.

\section{Author details}

'Zoology Department, Faculty of Science, New Valley University, El-Kharga, Egypt. ${ }^{2}$ Zoology Department, Faculty of Science, Assiut University, Assiut, 
Egypt. ${ }^{3}$ Chemistry Department, Faculty of Science, New Valley University, El-Kharga, Egypt.

\section{Received: 21 October 2020 Accepted: 4 March 2021} Published online: 19 June 2021

\section{References}

Abdel Gawad, S. S., Mansour, M. A., El-Tantawy, S. A., \& Heba, M. F. (2018), Histological study and ultrastructure of salivary glands of helicid snail Eobania vermiculata and planorbid snail Biomphalaria alexandrina (Gastropoda: Pulmonata). Egyptian Journal of Aquatic Research, 44(3), 219226. https://doi.org/10.1016/j.ejar.2018.09.002.

Abdel-Haleem, A. A., \& El-Kassas, N. B. (2013). Ultrastructure and histopathological effects of some plant extracts on digestive gland of Biomphalaria alexandrina and Bulinus truncates. The Journal of Basic \& Applied Zoology, 66(2), 27-33.

Abo Bakr, Y. (2011). Histopathological changes induced metaldehyde in Eobania vermiculata (Müller 1774). Alexandria Science Exchange J., 32(3), 300-310.

Ali, D., Alarifi, S., Kumar, S., Ahamed, M., \& Siddiqui, M. A. (2012). Oxidative stress and genotoxic effect of zinc oxide nanoparticles in freshwater snail Lymnaea luteola L. Aquatic Toxicology, 124-125, 83-90.

Berger, B., \& Dallinger, R. (1993). Terrestrial snails as quantitative indicators of environmental metal pollution. Environmental Monitoring and Assessment, 25, 65 e84.

Boer, H. H., Carry, M., Delft, M.-V., Müller, L. J., Kiburg, B., Vermorken, J. B., \& Heimans, J. J. (1995). Ultrastructural neuropathology effects of taxol on neurons of the freshwater snail Lymmnea stagnalis. Journal of NeuroOncology, 25, 49-57.

Bour, A., Mouchet, F., Silvestre, J., Gauthier, L., \& Pinelli, E. (2015). Environmentally relevant approachesto assess nanoparticles ecotoxicity: A review. Journal of Hazardous Materials, 283, 764-777. https://doi.org/10.1016/j.jhazmat.2014.10. 021.

Buzea, C., \& Pacheco, I. (2017). Nanomaterial and nanoparticle: Origin and activity. In M. Ghorbanpour, M. Khanuja, \& A. Varma (Eds.), Nanoscienceand plant-soil systems, (pp. 71-112). Switzerland: Springer International Publishing. https:// doi.org/10.1007/978-3-319-46835-8_3.

Coeurdassier, M., Gomot de Vaufleury, A., \& Badot, P. M. (2000). Dose-dependent growth inhibition and bioaccumulation of hexavalent chromium in land snail, Helix aspersa. Environmental Toxicology and Chemistry, 19, 2571-2578. https://doi.org/10.1002/etc.5620191025.

Datta, A., Patra, C., Bharadwaj, H., Kaur, S., Dimri, N., \& Khajuria, R. (2017). Journal of Biotechnology and Biomaterials, 7(3), 271

Davidson, M. S., Croteau, M. C., Millar, C. S., Trudeau, V. L., \& Lean, D. R. (2011). Fate and developmental effects of dietary uptake of methylmercury in Silurana tropicalis tadpoles. Journal of Toxicology and Environmental Health. Part A, 74(6), 364-379. https://doi.org/10.1080/15287394.2011.534427.

Dimkpa, C. O., Calder, A., Britt, D. W., McLean, J. E., \& Anderson, A. J. (2011). Responses of a soil bacterium, Pseudomonas chlororaphis O6 to commercial metal oxide nanoparticles compared with responses to metal ions. Environmental Pollution, 159(7), 1749-1756. https://doi.org/10.1016/j.envpol.2 011.04.020.

El-Okda, M. M. K. (1981). Land Mollusca infestation and chemical control in ElIsmailia governorate. Agricultural Research Review, Egypt, 62, 279-287.

Fahmy, S. R., \& Abdel-Ghaffar, F. (2014). Ecotoxicological effect of sublethal exposure to zinc oxide nanoparticles on freshwater snail Biomphalaria alexandrina. Archives of Environmental Contamination and Toxicology, 67(2), 192-202. https://doi.org/10.1007/s00244-014-0020-z.

Ferner, D. J. (2001). Toxicity, heavy metals. eMedical Journal, 2(5), 1 in: Qutob, 2013.

Gabr, W. M., Fatma, K. K., \& Hussien, S. S. (2007). Molluscicidal activity of some pesticides against glassy clover Monacha obstructa. Egyptian Journal of Agricultural Research, 8566, 2017-2025.

Gogos, A., Knauer, K., \& Bucheli, T. D. (2012). Nanomaterials in plant protection and fertilization: Current state, foreseen applications, and research priorities. Journal of Agricultural and Food Chemistry, 60(39), 9781-9792. https://doi. org/10.1021/jf302154y.

Hamed, S. S., Abdel Meguied, N. E., Essawy, A. E., Radwan, M. A., \& Hegazy, A. E. (2007). Histological and ultrastructural changes induced by two carbamate molluscicides on the digestive gland of Eobania vermiculata. Journal of Biological Sciences, 7(6), 1017-1037. https://doi.org/10.3923/jbs.2007.1017.103 7.
Heggelund, L. R., Diez-Ortiz, M., Lofts, S., Lahive, E., Jurkschat, K., Wojnarowicz, J., Svendsen, C. (2014). Soil pH effects on the comparative toxicity of dissolved zinc, non-nano and nano $\mathrm{ZnO}$ to the earthworm Eisenia fetida. Nanotoxicology, 8(5), 559-572. https://doi.org/10.3109/17435390.2013.809808.

Hernadi, L., Hiripi, L., Vehovszky, A., Kemenes, G. S., \& Rozsa, K. (1992). Ultrastructural, biochemincal and electrophysiological changes induced by 56- dihydroxytryptamine in the CNS of the snail Helix omatiaL. Brain Research $578,221-234$.

Hooper, H. L., Jurkschat, K., Morgan, A. J., Bailey, J., Lawlor, A. J., Spurgeon, D. J., \& Svendsen, C. (2011). Comparative chronic toxicity of nanoparticulate and ionic zinc to the earthworm Eisenia veneta in a soil matrix. Environment International, 37(6), 1111-1117. https://doi.org/10.1016/j.envint.2011.02.019.

Jeong, J. K., Lee, S. W., Hong, J. K., Shin, C. Y., \& Yun, J. G. (2012). Effective control of slug damage through tobacco extract and caffeine solution in combination with alcohol. Horticulture, Environment and Biotechnology, 53(2), 123-128 In: Hynes, 2015.

Jing, L. Q., Xu, Z., Sun, X. J., Shang, J., \& Cai, W. M. (2001). The surfaceproperties and photocatalytic activities of ZnO ultrafine particles. Applied Surface Science, 180(3-4), 308-314. https://doi.org/10.1016/S0169-4332(01)00365-8.

Kaegi, R., Ulrich, A., Sinnet, B., Vonbank, R., Wichser, A., Zuleeg, S., ... Boller, M. (2008). Synthetic TiO2 nanoparticle emission from exterior facades into the aquatic environment. Environmental Pollution, 156(2), 233-239. https://doi. org/10.1016/j.envpol.2008.08.004.

Kammenga, J. E., Dallinger, R., Donker, M. H., Kohler, H. R., Simonsen, V., Triebskorn, R., \& Weeks, J. M. (2000). Biomarkers in terrestrial invertebrates for ecotoxicological soil risk assessment. Reviews of Environmental Contamination and Toxicology, 164, 93-147.

Kumar, R., Kumar, G., Akhtar, M. S., \& Umar, A. J. (2015). Sonophotocatalytic degradation of methyl orange using $\mathrm{ZnO}$ nano-aggregates. Alloys and Compounds, 629, 167-172. https://doi.org/10.1016/j.jallcom.2014.12.232.

Lanno, R. P., \& Mc Carty, L. S. (1997). Earthworms bioassays: Adopting techniques from aquatic toxicity testing. Soil Biology and Biochemistry, 29(3-4), 693-697. https://doi.org/10.1016/S0038-0717(96)00197-6.

Lin, D., \& Xing, B. (2007). Phytotoxicity of nanoparticles: Inhibition of seed germination and root growth. Environmental Pollution, 150(2), 243-250. https://doi.org/10.1016/j.envpol.2007.01.016.

Ma, H., Williams, P. L., \& Diamond, S. A. (2013). Ecotoxicity of manufactured ZnO nanoparticles - A review. Environmental Pollution, 172, 76-85. https://doi. org/10.1016/j.envpol.2012.08.011.

Marigo'mez, I., Soto, M., Cajaraville, M. P., Angulo, E., \& Giamberini, L. (2002). Cellular and subcellular distribution of metals in molluscs. Micrcopical Research and Techniques, 56, 358e392.

Merdzan, V., Domingos, R. F., Monteiro, C. E., Hadioui, M., \& Wilkinson, K. J. (2014). The effects of different coatings on zinc oxide nanoparticles and their influence on dissolution and bioaccumulation by the green alga, $C$. reinhardtii. Science of the Total Environment, 488-489, 316-324. https://doi. org/10.1016/j.scitotenv.2014.04.094.

Mishra, S., Srivastava, K. S., Srivastava, R. K., Panday, A. C., \& Prakash, S. G. (2011). Sonophotocatalytic degradation of methyl orange using $\mathrm{ZnO}$ nanoaggregates. Advanced Materials Letters, 2(4), 298-302. https://doi.org/10.51 85/amlett.indias.210.

Moens, R., \& Glen, D. M. (2002). Agriolimacidae, Arionidae and Milacidae as pests in Western European oilseed rape. In Gastropod pests on oil see trape, in molluscs as crop pests, (pp. 425-440). Wallingford: Edited by BarkerG.M. CABI Publishing.

Mustafa, O. M., \& Awad, I. R. (2018). Studies on the histology, histochemistry and ultrastructure of the digestive gland of the slug lehmannia marginata (Gastropoda: Pulmonata). Egyptian Journal of Zoology, 69, 43-53.

Nash, M. A., Thomson, L. J., \& Hoffmann, A. A. (2007). Slug control in Australian canola: Monitoring, molluscicidal baits and economic thresholds. Pest Management Science, 63(9), 851-859. https://doi.org/10.1002/ps.1411.

Pack, E. C., Kim, C. H., Lee, S. H., Lim, C. H., Sung, D. G., Kim, M. H., ... Kim, S. W. (2014). Effects of environmental temperature change on mercury absorption in aquatic organisms with respect to climate warming. Journal of Toxicology and Environmental Health. Part A, 77(22-24), 1477-1490. https://doi.org/10.1 080/15287394.2014.955892.

Parisi, C., Vigani, M., \& Rodrígues-Cerezo, E. (2015). Agricultural nanotechnologies: What are the current possibilities? Nano Today, 10(2), 124-127. https://doi. org/10.1016/j.nantod.2014.09.009.

Pihan, F., \& de Vaufleury, A. (2000). The snail as a target organism for the evaluation of industrial waste dump contamination and the efficiency of its 
remediation. Ecotoxicology and Environmental Safety, 46(2), 137-147. https:/ doi.org/10.1006/eesa.1999.1891.

Pinto, E., Sigaud-Kutner, T. C. S., Leitão, M. A. S., Okamoto, O. K., Morse, D., \& Colepicolo, P. (2003). Heavy metal induced oxidative stress in algae. Journal of Phycology, 39(6), 1008-1018. https://doi.org/10.1111/j.0022-3646.2003.02-193.X.

Punnoose, A., Dodge, K., Rasmussen, J. W., Chess, J., Wingett, D., \& Anders, C. (2014). ACS sustain. Chemical Engineer, 2, 1666-1673.

Ramzy, R. R. (2009). Biological and ecological studies on land snails at Assiut, Egypt MSc. Thesis, Faculty of Science, Assiut University, Egypt, (p. 164).

Romero-Freire, A., Lofts, S., Martín Peinado, F. J., \& van Gestel, C. A. M. (2017). Effects of aging and soil properties on zinc oxide nanoparticle availability and its ecotoxicological effects to the earthworm Eisenia andrei. Environmental Toxicology and Chemistry, 36(1), 137-146. https://doi.org/10.1002/etc.3512.

Sales, J. (2013). Effects of pharmacological concentrations of dietary zinc oxide on growth of post-weaning pigs: A meta-analysis. Biological Trace Element Research, 152(3), 343-349. https://doi.org/10.1007/s12011-013-9638-3.

Sanchez, M. L. (2008). Causes and effect of heavy metal pollution. Hauppauge. New York: Nova Science Publishers.

Segatto, C., Ternus, R., Junges, M., Mello, J. M. M., Luz, J. L., Riella, H. G., ... Fiori, M. A. (2018). Adsorption and incorporation of the zinc oxide nanoparticles in seeds of corn: Germination performance and antimicrobial protection. IAERS, 5, 2349-6495.

Service, R.F (2008). Report faults US strategy for nanotoxicology research. Science, 322(5909), 1779. https://doi.org/10.1126/science.322.5909.1779a.

Shankar, R., Srivastava, R. K., \& Prakash, S. G. (2013). Study of dark-conductivity and photoconductivity of $\mathrm{ZnO}$ nano structures synthesized by thermal decomposition of zinc oxalate. Electronic Materials Letters, 9(5), 555-559. https://doi.org/10.1007/s13391-013-2166-7.

Sharaf, H. M., Salama, M. A., \& Abd El-Atti, M. S. (2015). Biochemical and histological alterations in the digestive gland of the land snail Helicella vestalis (Locard, 1882) exposed to Methiocarb and Chlorpyrifos in the laboratory. Journal of Cytology and Histology, 6(3), 334-343.

Snyman, R. G., Reinecke, A. J., \& Reinecke, S. A. (2005). Quantitative changes in the digestive gland cells of the snail Helix aspersa after exposure to fungicide copper oxychloride. Ecotoxicology and Environmental Safety, 60(1), 47-52. https://doi.org/10.1016/j.ecoenv.2003.11.008.

Sturikova, H., Krystofova, O., Huska, D., \& Adama, V. (2018). Zinc nanoparticles and plants. Journal of Hazardous Materials, 349, 101-110. https://doi.org/10.1016/j. jhazmat.2018.01.040.

Viard, B., Pihan, F., Promeyrat, S., \& Pihan, J. C. (2004). Integrated assessment of heavy metal (Pb, Zn, cd) highway pollution: Bioaccumulation in soil, Graminaceae and land snails. Chemosphere, 55, 1349e1359.

Wangsomnuk, P., Upatham, E. S., Kruatrachue, M., Chitramvong, Y., \& Sertarugsa, P. (1997). Histological alterations in the reproductive, nervous and digestive systems of Indoplanorbis exustusin toxicated with molluscicides. J.Sci.Soc.Thailand, 23(4), 281-296. https://doi.org/10.2306/scienceasia1513-1874.1997.23.281.

Wensen, J. V., Vegter, J. J., Straalen, V., \& N.N. (1994). Soil quality criteria derived from critical body concentration of metals in soils invertebrates. Applied Soil Ecology, 1(2), 185-195. https://doi.org/10.1016/0929-1393(94)90037-X.

Yousef, H. N., Beltagi, S. M. H., Al-Shinawy, M. S. A., \& Elkattan, N. A. (2011). Effect of certain plant products on some physiological and histological aspects of the terrestrial snail, Eobania vermiculata, in Egypt Ph. D. Thesis, Zoology Dept. Fac. Edu., Ain Shams Univ

Zaldibar, B., Cancio, I., Soto, M., \& Marigómez, I. (2007). Digestive cell turnover in digestive gland epithelium of slugs experimentally exposed to a mixture of cadmium and kerosene. Chemosphere, 70(1), 144-154. https://doi.org/10.101 6/j.chemosphere.2007.06.071.

Zhou, X., E, S., Upatham, M., Krustachue, P., \& Sretarugsa, P. (1993). Effect of Niclosamide and Eucalyptus camalduiensis on Biomphalaria slabrata the snail intermediate host of Schistosoma mansoni. Journal of the Science Society of Thailand, 19(3-4), 117-128. https:/doi.org/10.2306/scienceasia1513-1874.1993.19.117.

\section{Publisher's Note}

Springer Nature remains neutral with regard to jurisdictional claims in published maps and institutional affiliations. 